THE UNIVERSITY

OF ILLINOIS

LIBRARY

1915

K29 


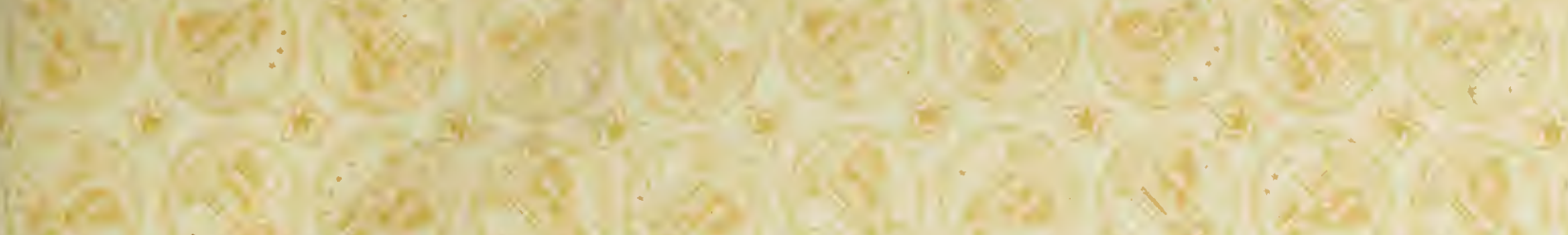

\section{$2 x-2$

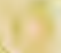
40
$9=$

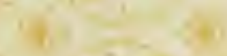

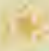

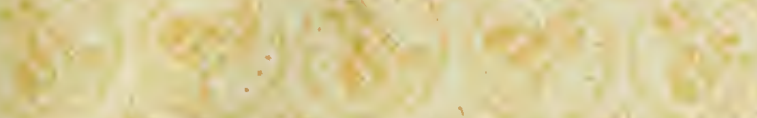

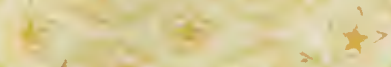

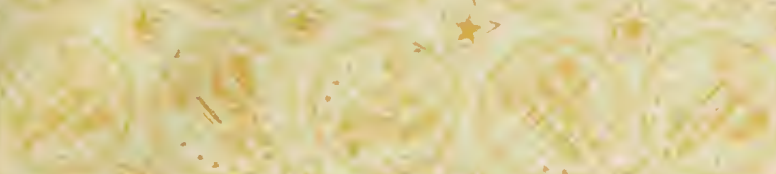

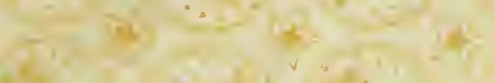

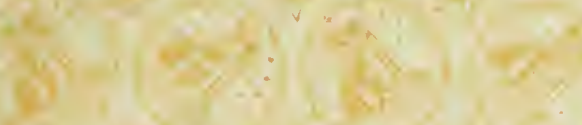

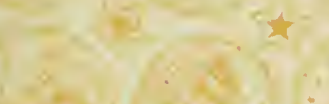

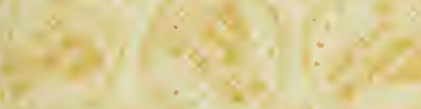

y-

84

$=\ldots$ is $\therefore$ is is

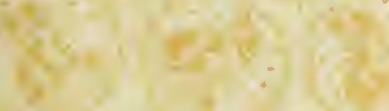

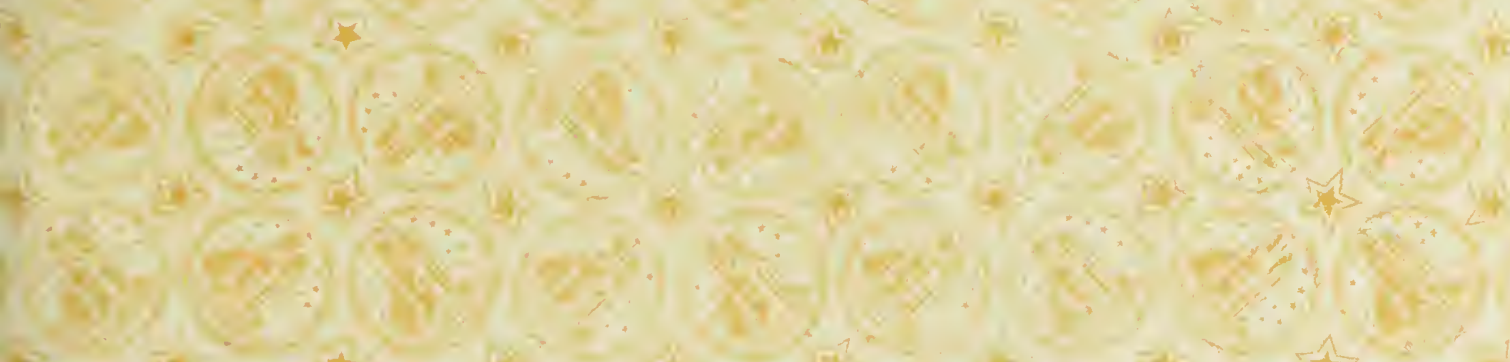

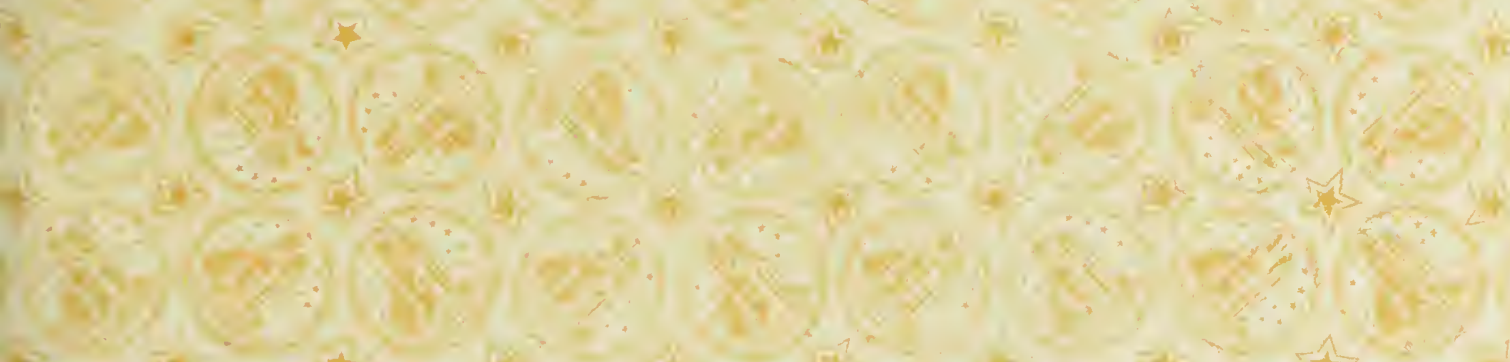

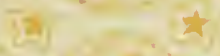

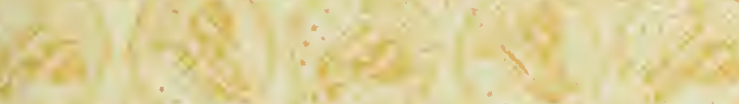

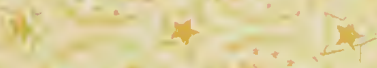

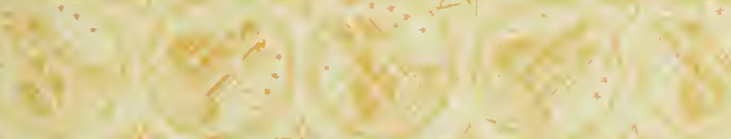

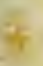
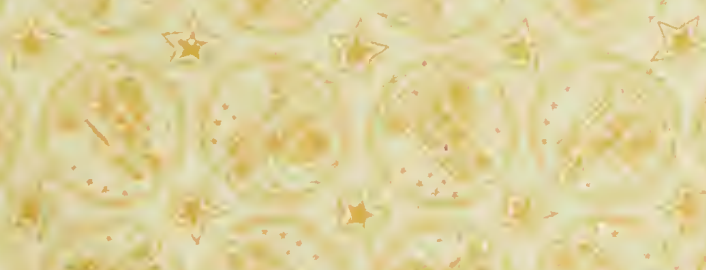

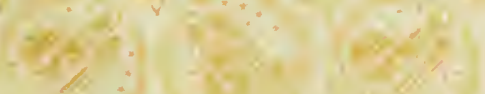

tis

.

A. ${ }^{\prime}$

$3^{i}-2+2$

$-2=19$

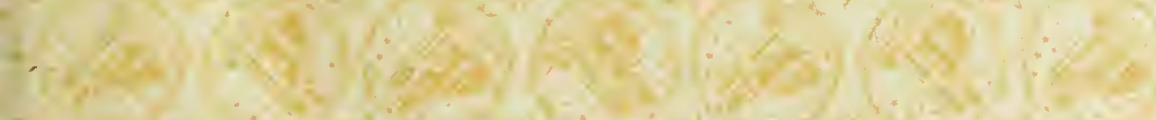

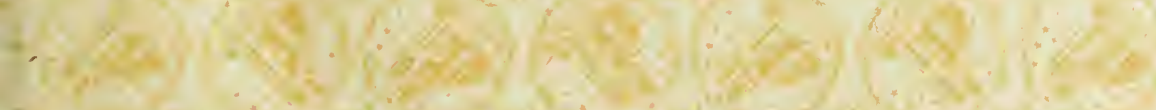

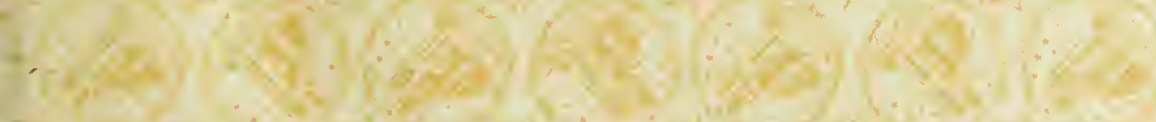

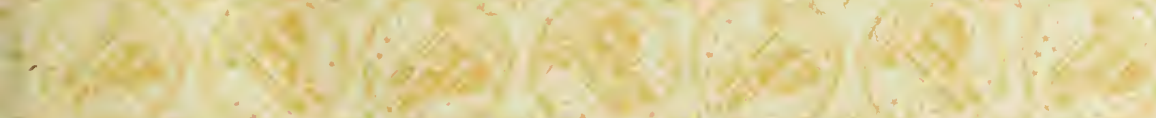

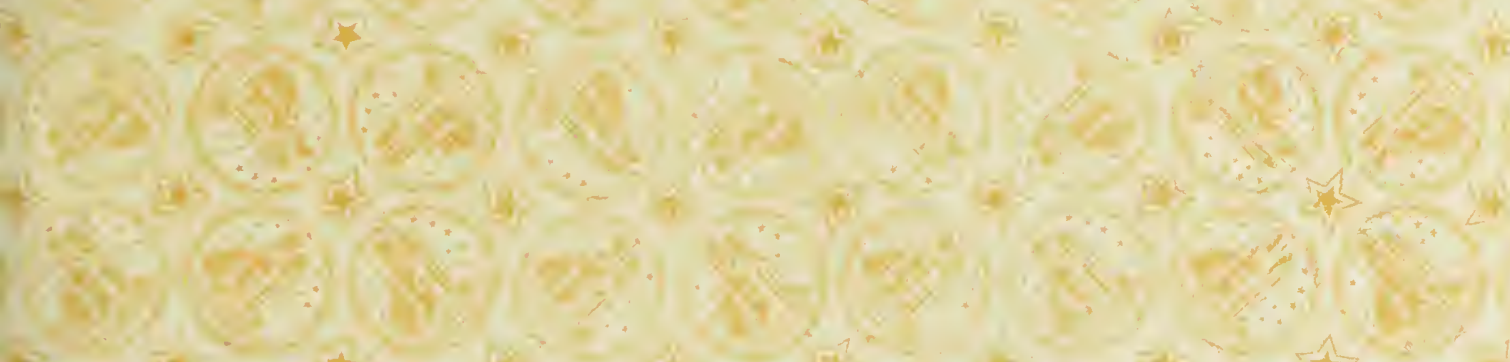

$(8)$

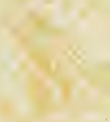

$4=$

$3 \times$

$x^{2}=8$

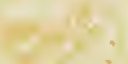

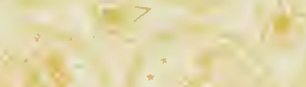

$4 y=\ldots 1 \% \div$

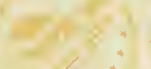

$x+$

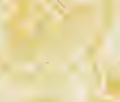

7
7
4 ty.

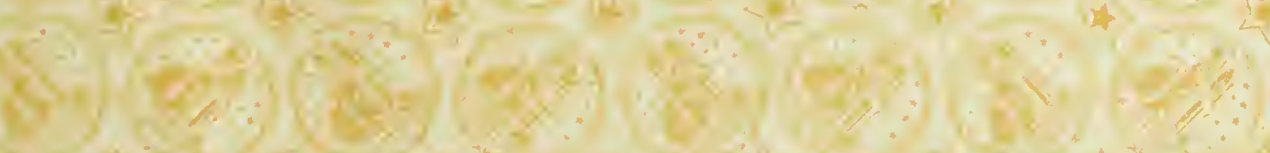

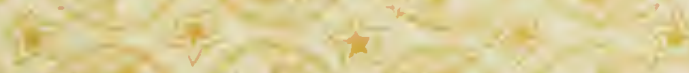

70

18

S.

造

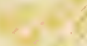

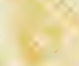





\title{
THE ANATOMY OF SOME DESERT PLANTS
}

BY

\author{
AMELA L. KELLOGG
}

\section{THESIS}

\author{
FOR THE
}

DEGREE OF BACHELOR OF ARTS

IN

SCIENCE

COLLEGE OF LIBERAL ARTS AND SCIENCES

UNIVERSITY OF ILLINOIS

1915 
Digitized by the Internet Archive in 2013

http://archive.org/details/anatomyofsomedes00kell 
THIS IS TO CERTIFY THAT THE THESIS PREPARED UNDER MY SUPERVISION BY Amelia l. Kelloge.

ENTITLED The Anatomy of Some De........ Plants

IS APPROVED BY ME AS FULFILLING THIS PART OF THE REQUIREMENTS FOR THE DEGREE OF Bachelor of Arts in science
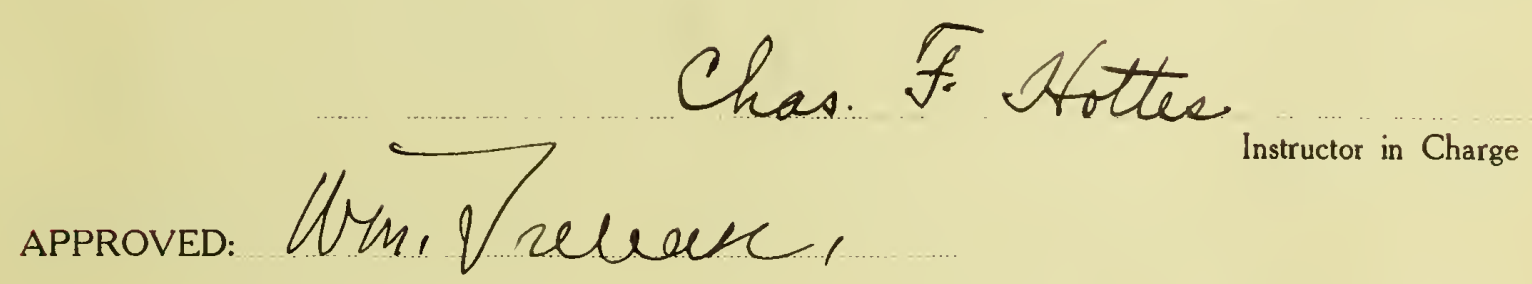

HEAD OF DEPARTMENT OF.

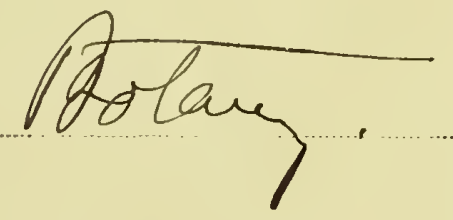



1915

Contents.

A. Introcuction.

3. liethods.

C. Anstouical Studies.

I. Chorojeqiacea

1. Atrojider canesens.

$.1-2$

(a) Etem.

.2 .8

(c) Lesin.

.2 .5

$.3-5$

.3

. ' f

2. Atrifiex Nutallii corrucata. .5

II. Loaseae.

.5 .7

1. *uentzeIia. mit1fIcra.

(a) Ster.

(b) Leaf.

.6

.7

III. Posaceas.

1. Cercocarpus ledifolius.

(a) Eter.

.7

(b) Leaf

.7

.8

D. Plates 



\section{The Anatomy of Some Desert Plants.}

The anatomy of ralatively few American plants has been studied in detail. Solerader in his vary excellent work, "The Systematic Anatomy of Dicotyledons", has brought together the chief anatoric features that characterize the families of dicotylodonous plants and a careiul examination of this work reveals the fuct that Amarican botanists have contributed very Iittle to the subject.

The groatest variation in anatomic structurs is show in the families Whose representitives possэss tho widest adaptibility to environnental conditions. Schimper, Marming, Volkens and others in their ecologic studies have called special attention to chenges in anatomic structure induced by environmsntal conditions, chiefly physical. It is with the viev of adding a little to our knowladge of the anatomy of American plants, partiavlarly such as have adsptod themsel ves to extreme conditions, that the present study was undertaken. The plants studied are :

(1) Atripləx canessns, Wats.

(2) Atriplex Nutalii corrugata, A. iNols.

(3) Montzelia nultiflora, Graj.

(4) Carcovarous ledifolius, H.B.K.,

of the families Chonopodiaceae, Loasear, and Rosaceas respectively.

The daterial was collectad in the Colorado Desert, nems Palisaje, Colorado, at an elovation of between five and sevan thousand feet aiove seat level, and preserved in a mixture of the following comosition:

$$
\begin{aligned}
& 850 \text { cc. water, } \\
& 36 \mathrm{cc} \text {. formalin }
\end{aligned}
$$





\section{$250 \mathrm{cc}$. alcohol (ninety-five per cent)}

In the proparations of sections suitable for anatomic study, great difficultiog wero experienced due to the extrene haruness of the more resistsnt tissues of both leaf and stom. The material embedded by the ordinary wethod in parafin cr colloidin wes utterly worthless for study. Soaring in alcohol and slycerine with or without subsequent embedding, gave no better resulta.

Finally, the method so successfully employed by Jefiriss and Plomman was triad and found to Iive good results. Tho preserved matorial was washed for some time in eighty per cent alcohol, and was then transferred into parafined bottles containing a ten per cent solution of hydrofluric acid. In this acid, Tith two changes of solution, it romainad for two vaeka. The material was then waghed in flowing water to rerove the acid, dohydrated by passing it through solutions of tinirty, fifty, seventy, eighty, ninoty, ninety-five per cont, and absolute alcohol resrectively, and embedded by the ordinary process in paraffin or celloidin. The harier, wore resistant stems and mors brittlo leaves were infiltrated and embedded in colloidin. The infiltration was acc craplished by transferming the tissues successively into tro, four, six, :-3it, ten, and fourteen per cent solutione of coliciain in equal parte of ebsolute alcohol chd ether. The mata:i I reveined in the two, four, gix, ileht, and ten per cent aolutions, respectively, for two days, s.nd in the Eourteer per cent for two wo ks. It was then exbedaed in the usval ranner.

Tho sections were stained in Biriark browd, fuchsir and eosir. In soma cises, it was fourd fossible to study and araw stricture in detail witholit previcus staimine of the sectiors.

1. Atriflex canssere, Tiats. (Chenopodeaceat)

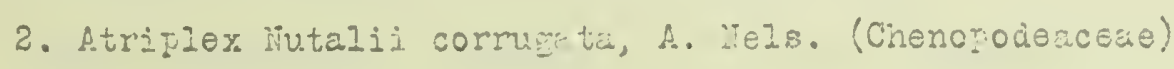



3. Mentzelia multiflora, Gray (Loaseae)

4.Gercocarpus ledifolius, H. B. K. (Fosaceae)

The widely different stem stricture in the Chenopodeaceae led

De Bary ${ }^{2}$ to clasify such sters into three classes $\exists$ follow:

1. The growth in thicknoss of tine stem is due to the formation of pericyclic rings or strips of cambium which originate and lose their activity successively, forming secondary bundes and conjunctive tissue. The successive rings thus formed vary sorewhat in reglilarity anci completenoss.

2. The growth in thickness following the formation of the ring of bundes, results from the appearence around the margins of the thloem, of a ring of interfacicular cambium vinich forms altornately vascular bundes and intemediate tissue.

3. In the final type, a combination of the processes 1 and 2 takes placo, that is, tho normal cambilia and normal secondary thickonine appear as in type 1; tris however, socn stops and further growth in thickness is continuod by a now extre fasecular zone of cambium which appears outsiae the primary Inasses of phloan - accoraing to typo 2.

Solereder's classification disregards type 3, groupine all stem structures uncier the tho extreme tyces descrioad oy De Bary.

Atriflex canesens.

The stom structure of Atriclex canesens may be considered as belon:ing to tyxe 2. The vascular bundes are embedied in prosen chytatous conjunctive tissle enä arrangea without definite regularity. The conjunctive tissue is conspicuous in that it is corposed of very thick-walled cells containing simy lo pits. The arrengerent is irregular, and nowhere are clearly defined medulary rays visible.

Within the vascular cylinaer is a rethor large pith composed of 

large cells full of protoplasu and so closely crowded as to admit of no intercellular spaces.

The primary cortex is corposed of parenchyma, irregularly broken areas of collenchyma, and an abundance of sclerenchynous fibres scattered along the outer margin. The cortex is bounded by a single layer of thickwalled exidermal cells.

The surface of the stem is covered with a membranous covering of collapsea water-storage hairs. Theae are unicellular, irregular in size and shape, and epidemal in origin. They are very numerous and, when they collapse upon maturity, forn: a dead memoranous covering that serves to chack transpiration. The leaf of Atriflex canesens is covered by sirilar hairs, (Fig. 1-2PlateI)

The most striking anatonic character brought out in the crosssection of the leaf is the absence of the visual spongy parenchyma, the greater part of the leaf being made up of elcngated chlorophyll-bearing cells not unlike the pallisade cells of ordinary leaves. (Fig. I PlateI) Very few intercellular spaces are apparent in the transsection.

The vascular bunoles are located centrally within the pallisade tissue. They are characteristically surrounded by a sheath of large, thickvalled cells, noarly circular in cross-section. (Fiz. Z Plate I)

Crystals of oxalate of lime occasionally occur ir the form of cluster crygtals in the various tissues excerting only the vascular bundes. The upper anc lower epideruis are exactly alike. Each is composad of a single row of thick-walled cells without gelatinization or waxy defosit. In both, stomates are fairly aunaant and are unaccompanied by subsidiary $\operatorname{cel18.}$

In the leaf, as in the stem, protection against excessive transpiration is well provided for by a membanous covering of collapsed hairs, 

Previously doscribod in connoction with tho stom. (Figrol-2Plate I)

\section{Atriplex Nutalii cormagata.}

The anetomy of Atriplex Nutalii corrugata, the second species of Atriplox exinined, is so nearly identical with the above described spocies as to warrant no furthor cominent on atructural detaila. Both correspond very closaly to Atriplex Hanilus describod by Volkens in his study of EgypticuArabian Desert plants. 4

The most imoortant anatomionl character of the family of Loaseae is its hairy covaring. The haira may be deacribed as :

1. simple, unicellular hairs of varied length whose walls way or may not be silicified;

2. unicellular, conical, charp-pointed hairs and strongly silicified. The surface is covered with sharp or blunt spines directed eithor forward or backward;

3. unicallular, strongly silicified, barbed hairs of variable longth and often comparablo to a many-fluked anchor. The stalk is sometimes covered with recurved spines;

4. long, uniceliviar, hooked, or climbing hairs with a high multicellular base. Those bear soveral shart hooks at the apex and show activo Droto:lasmic movement;

5. lons, unicellular, slightly silioified, sickle-like hairs, without protoplasraic ravement;

6. unicellular kairs, slenäerly filiform, wi th lockl tuber-like swellinge at the base and sharply attenuatod at the apex or apex with barbs;

7. long, strongly silicified, unicellular stinging-hairs with a multicellular baze anc frequently containing a yellow fluid which has a very irritating eff эct upon animals; 

8. short, simtle, multicellular hairs;

9. multicellilar Glandular haire with ar uniserate stalk of variec length and vith a unice:lular head.

Other characters essential to the Loascae are hairs that are calcifiec rither than silicified; also crystolith-like stmicturee for the nost fart impogated with carbonate-of-line. These usucily occur in the unicellular bars, excenting only the stinging hairs, and their subsidiary celis."

\section{Wentzelia multiflora.}

lientzeliz mltiflora yossesses the several kinds of hairs described unier tjues 1, 2, 3, and 6, excertine that they are calcified rather than silicified. This is proved by the fact that they withstood most rigeid treatment with the hydrofluric acid that was lieed in the provaration of sectione for study. Others are crystolith-like stnictures ingrecnated with carbcnateof-line. Thess are restricted to the larger unicellular haira and their subsidisry cel1s.

The gteri consists of a woody cylinder, incluaine narrow mecullary rays, fairiy wide vessels with simple verforations and with cordered pits in cortact mitr. garenchyra as wall az the wcod grosenchym. The wood prosenchyma has iairly wide lunina. (Fig.l Plote II ).

Other tissues are a central pith corrosed of larte, smewhet en wular thick-wallea cells; a well rarked cavoium; and a pericycle of large irregularly shaped varenchyra colls. The epidsmal cells vary in size and shape from the crinary brick-shaped cell to the more complex hair-iike structura, previcuily described. (Fig. I PlateIII).

The leaf of lientzelia mutiflcra is oval in cross-section. Regaraing its structure, it ray bo pointed out that tho stomata have no subsidiary 

colls, but aro surrounded by a variablo number of orainary epidernel cells. They occur at irregu?ar intervals throuchout the ring of epidermis.

There is a rather congpicuous centril vein with olearly differentiated zone of xylex ans phloes, - also a network of tricheids running free in the mesophyl.

The resophyl consists of a spongy parenchyma surrounding the central voin, gradually bocoming differentiated into pallisade-lizo cells as it approaches the epidoruis. (Fig. I Plate II).

The epidemis of the laaf is similar to that of the stem excopt that the cells are larger in proportion and thicker-walled and tine hairs are longer and stronger. Upon the outer surface orcurs a triple layer of cutin not present on the opidermis of the storn. (FiE. I PlateII).

Specific anatorical charactors are almost entirely lacking in the Rosuceae. Accoring to Solereder and others the following are the most prevalent charactars:

1. the iack of siaple uniseriate clothing hairs;

2. the presence of bordered fits in the prosenchywatous groundworl of wood in almost all woody spacies.

Cercocarpus leaifolius.

The ster of Cervocarpus ledifolius is typically moody and possesses boràered its in the proasnchymatous groundwork of wood. The vascular cylinder is a fairly wide rogion consisting of small luminad wood cells and narrow redullary rays extending as a conepicuous band out through the rather will preserved phloom. There is a central pith of large circular heavy-wailed cells. The cort $x$ is rather wide and consists of irremlarly shapod parenchym cells, increasing in 8 izo as they near the eviderrais. The exidermis consiats of small, circular celis, regular in aize and shape, and 

With a thick doposit of cutin on its outgr suriuce. (Fig. 2 Plato IK).

A large amount of tannin and silica, doposited in the colis of parenchymatous tissues of this sten, givos it a very conspicuous character.

The leaf of this sare plant is peculiar in cross-section in that there is a prominent wik-rib from wich the blade curls bsch on oither side, giving the entire structure an apjearance not unlike the figure three. This miarib contains a single vein with a definits xylem and ghloem broken by narrow cands of narenchyma cel1s. (Pig. 1. Plate II ). Bolow the mid-vein is a creseent oi spongy parenchyna weoting the small crowded pallisade-like 2011s above - which comprise the bulz of the tuterre? tisaues. The 12torel

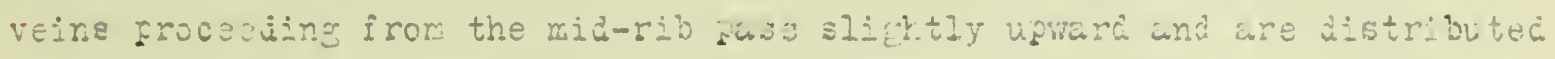
trrough the mesodrya. Each of the lateral. veins is surrounded by a sheath ci heary-ralled cells, one layer deeg. (Fig. ( PlateI).

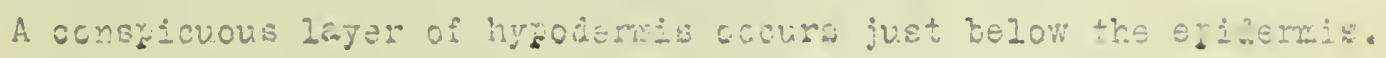
It $-s$ compos of of arge thick-wajles cells Ebundantiy supplied with tannin. This is also tmue of the cells conjosing the bundle-sheaths.

The eiliemris consists of a single layer of very srail cells vith a Meli develozod doposti of cutin on the cuter surface. Stovatec are ahunciart cn the lower surface of the leaf. Transpiration is reauced by a derse rat of unicolluzar clothing hairs and the peculiar curlixg of the leaf. The hairs are entirely restricted to tre under surisce ci the ieaf or either sice of the frowinert ridurib. (Fig. 1 PlateI ).

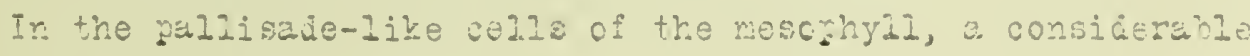
Guantity of sijica is copositso.

In the study of the above Arericar desert panta, belcnjin te the

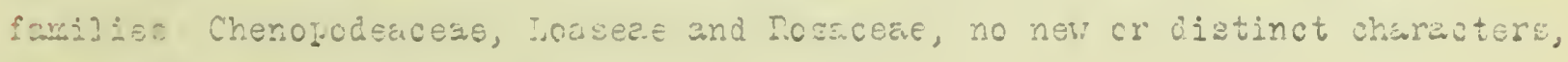
nct areazy roteo, sere discovered. 

References.

Jeffries - Ploman: Botanical Gazette, Volume XxXVII June $1904, p p .456$.

${ }^{2}$ De Bary: Comarative Anatomy of Phanerogums and Fems, DP. 490.

3oloreder: Systorcatic Studies of Dicotyledons, to 655. 4olkens: The Flora of the Egyptian-habian Fesert. 5observed by Solereder: The Systematic Stuoy of Disctyledons, 2p.380. 


$$
\text { Plate ב. Figurs 1 - } 2 \text {. }
$$

Uiduie and end sections of the crose-section of the leaf of d.trirlex canesens - showing covertirg of colnapad wutan-storuce hairs - bundle sheathe, - pallisade-like resophyll, otc. 

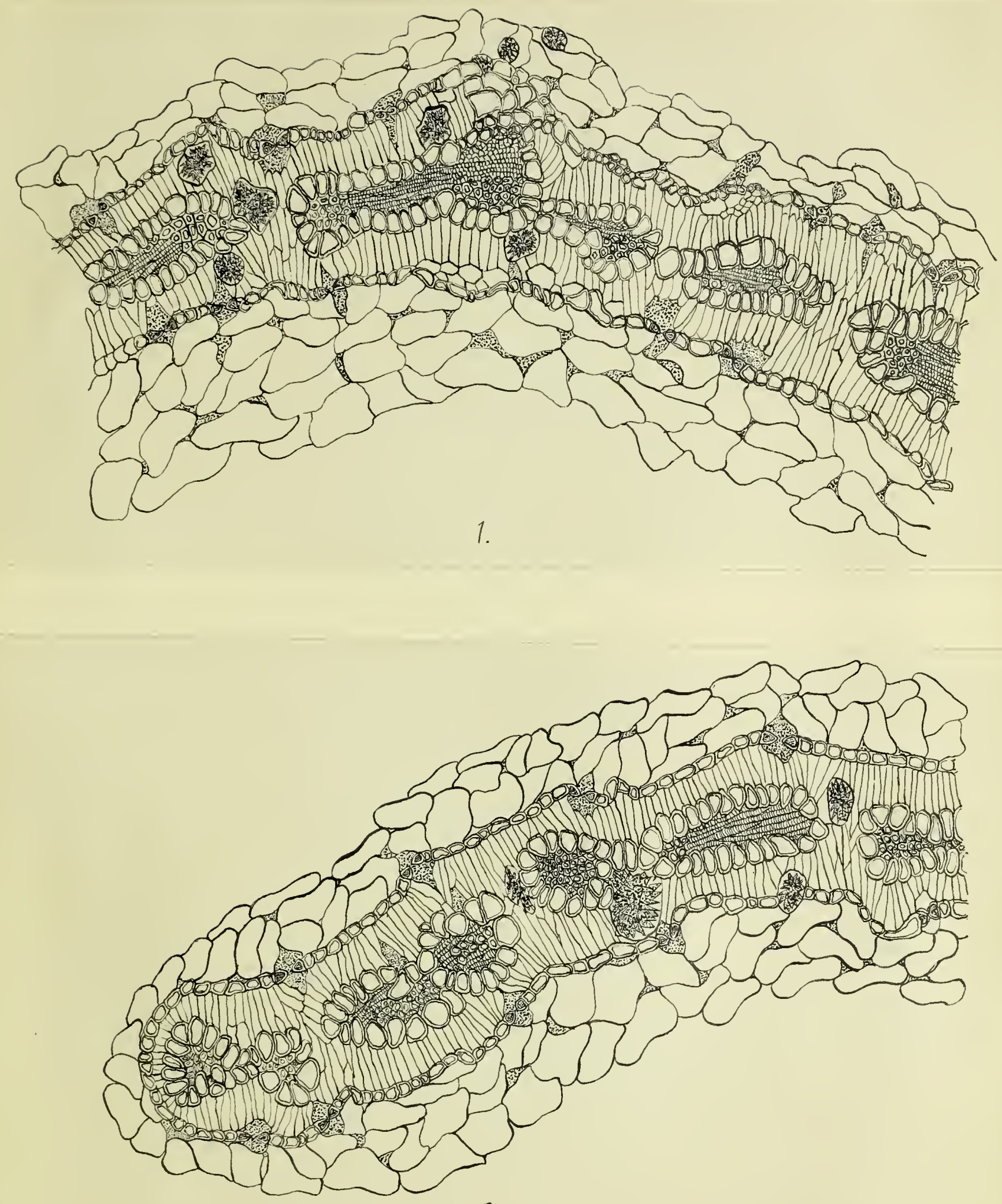
Plate 2. Figure I.

Cross-aecticn of the leaf of ventzelia multiflora, shoring wiamvin (xylem and rhloer) - netrork of tracheids munine free in mesoingil - hooked trichomes, ete. 


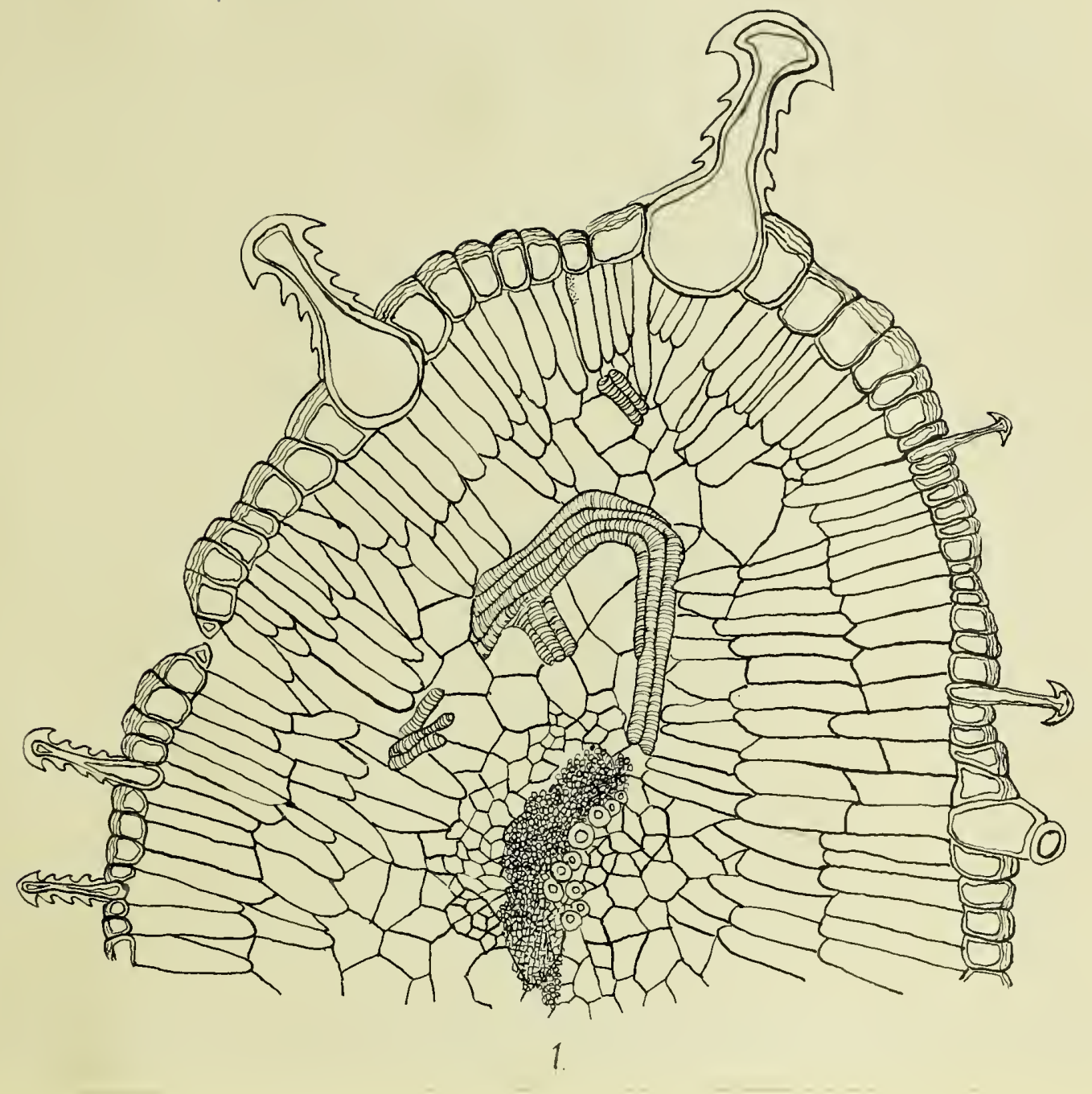


Plate 3. Figure 1.

Crosi-zection of the ster. of Nentzeliz multi-

flora - ahowing the relative location of tiscues.

Flate 3. Fignere 2.

Crosa-section of the sterr of Cercocarpus leajfolius

- shoring tre locatior of tissues. 
Plate 4. Fíguro 2.

Widaie part of cross-sectson of the leaf of

Cerocarrus ledifolivs - showing the wid-vein

and other rost conspicuous characters. 


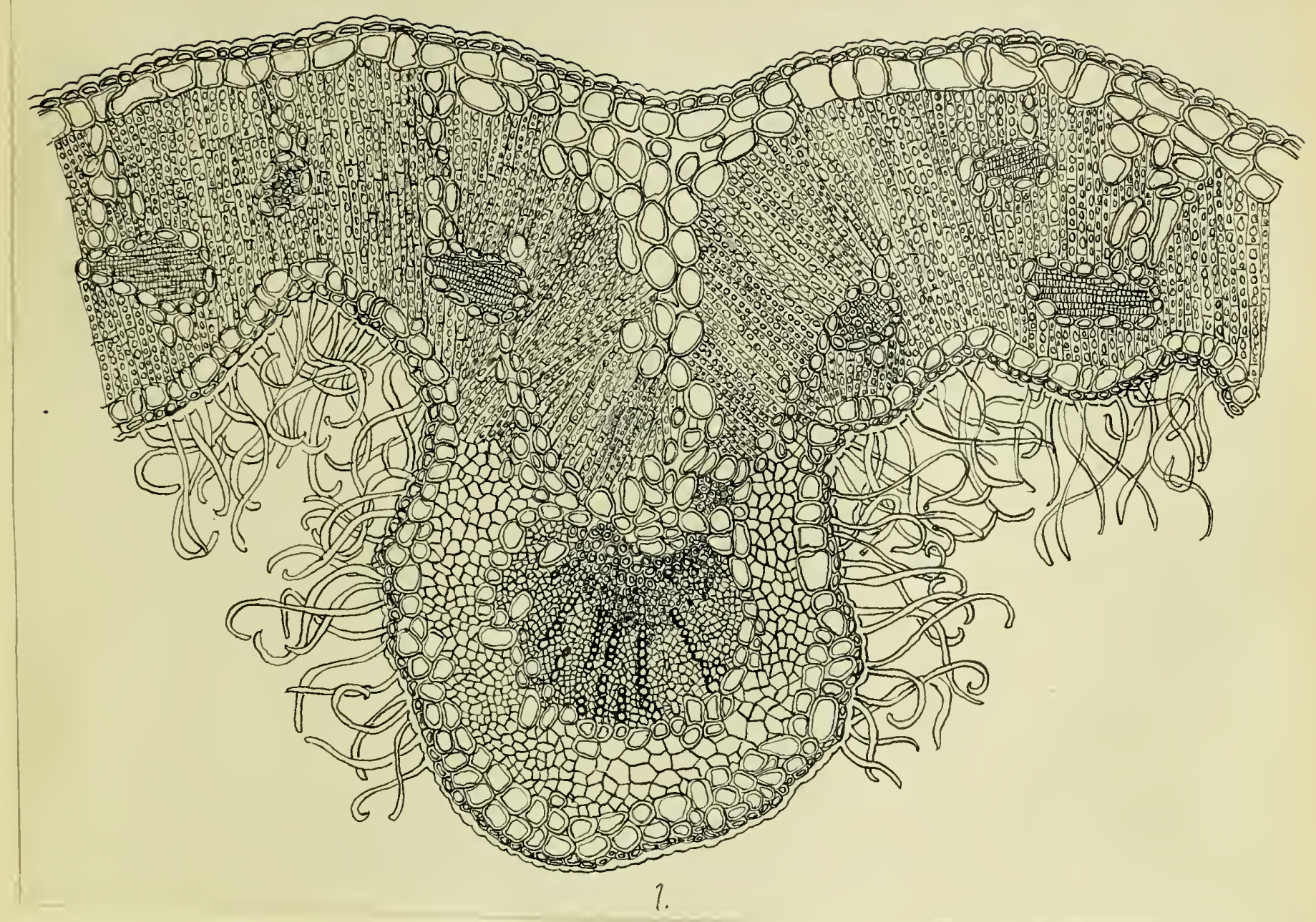


Plate 5. Ficure 1.

Crcasusection of the leaf of Cercocartus

ledifolius - shoving curled blade, locaticn

of stcrata, hairs, etc. 


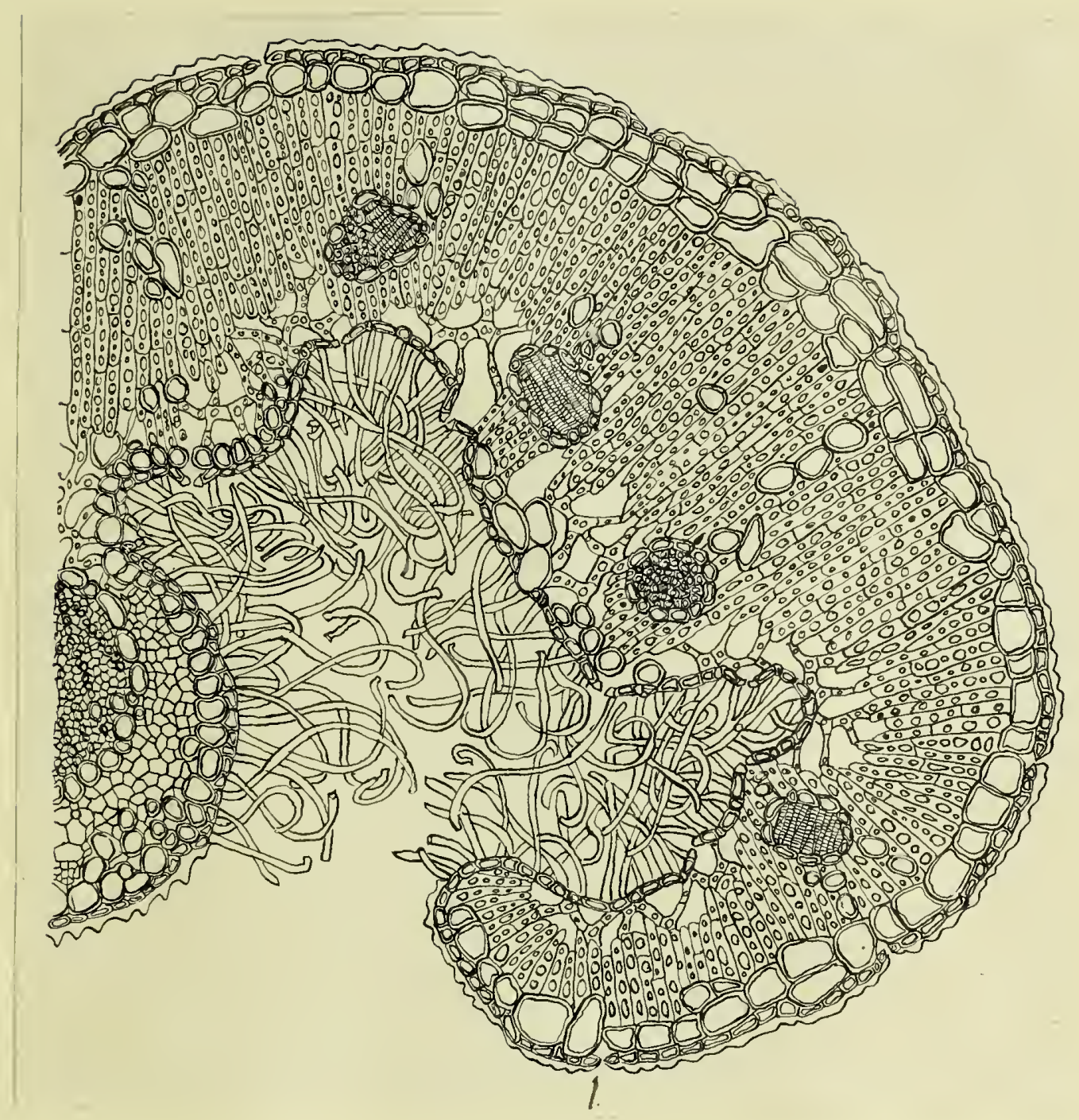




is 40.

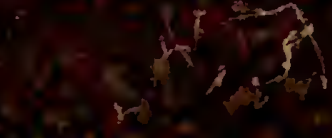
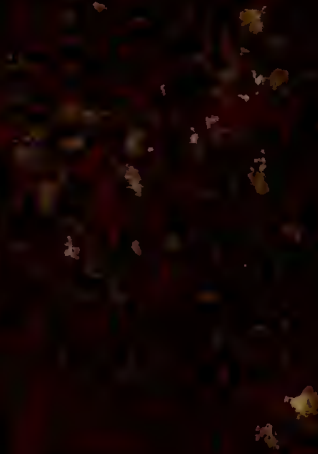

(3) $13=$

4 